any advance in education after the War would be impossible without a proper supply of teachers, and that the proposed call-up would paralyse the whole educational scheme of the country.

Mr. McCorquodale, Parliamentary secretary to the Ministry of Labour, replying to the debate, said that the medical schools would decide on the basis of the first examinations which students would be granted deferment. Scientific students would be recommended for deferment by the University Joint Recruiting Boards. The Minister of Labour had decided that he could no longer allow boys whose medical grade was sufficiently high to make them liable to serve to go up to the university to take an arts course for one year. This decision would entail the closing down at the end of the summer of the present year's university arts course with the exception of those who were medically unfit for the Services. As to the question of mathematics, if a scientific student persuaded the Recruiting Board that his course was in the interest of the prosecution of the War, he would get facilities for carrying it through. The Bill was read a third time.

\section{Radio Research for the Services}

Mr. Lyttelton, Minister of Production, said in the House of Commons on December 9, that in view of the great increase in the importance of wireless communication and radio-location during the War, the Government has set up a Radio Board as the co-ordinating body in regard to inter-Service policy, research, development and production. The Board is in general responsible to the Minister of Production, but where matters of service policy are concerned it takes its instruction from, and is responsible to, the Chiefs of Staff Committee. The Minister Resident for Supply in Washington (Colonel Llewellin) acted in his personal capacity as the first chairman of the Board. On his appointment to Washington he was succeeded by the Minister of Aircraft Production, Sir Stafford Cripps, also in his personal capacity. The chairman is assisted by two deputy chairmen, the Parliamentary Secretary to the Ministry of Supply (Mr. Garro-Jones) and Prof. G. P. Thomson. The membership of the Board includes representatives of the Admiralty, War Office, Air Ministry, Ministry of Supply, Ministry of Aircraft Production, and General Post Office, as well as several special nondepartmental members. Much of the work of the Board is carried out through two main working committees, the Production Planning and Personnel Radio Committee and the Operations and Technical Radio Committee, of which Mr. Garro-Jones and Prof. Thomson are respectively chairmen.

\section{New Light Day Bomber for the R.A.F.}

RECENT reports of a day raid upon Eindhoven, Holland, mention for the first time the use of the Lockheed Ventura I. The R.A.F. type is presumably a development of the American machine, originally known as Lockheed Vega 27. This model is powered by two 2,000 h.p. Pratt and Whitney Wasp 18cylinder radial engines, and has a speed of 275 miles per hour, with a range of 1,500 miles. It carries a crew of four or five, as necessary, and has armament of two movable and two fixed guns in the nose, a Boulton and Paul gun turret on the top of the body, and two movable guns underneath. It is probable that the improved version is superior to this in both performance and armament. The most significant point about the aircraft is that it is a further step towards completing a range of high-performance bombers and fighters that, in total, form a team for heavy day bombing, working upon the theory of smothering the defence when attacking. The Boeing Fortresses operate at great heights, Liberators at a little less, with Venturas, Mustangs and Mosquitoes lower down, even to ground-level. The high speeds and good manœuvrability of these machines make them able to take reasonable evasive action when attacked by anti-aircraft fire, their performance is comparable with British fighters, simplifying the question of their being escorted, and even unescorted their armament and mancuvrability allow them to put up a good defence against enemy attacking fighters.

\section{Recruitment of the Civil Service}

THE sixteenth report of the Select Committee on National Expenditure, in a section dealing with the recruitment of the Civil Service, includes some account of the Appointments Department of the Ministry of Labour and National Service, created on March 1, 1942, in which the old Central and Supplementary Registers have been merged, which should be of interest to scientific workers. As a recruiting agency the Ministry's organization now also includes the Temporary Government Service Registers and the Central Register of Aliens, and in regard to the latter, the report recommends that a much more vigorous attempt should be made to keep the Central Register up to date and to find suitable employment for the persons whose names it contains. Reviewing the operation of the Central (Scientific and Technical) Register, the report comments on the relatively slight use made of this Register by industrial firms as compared with Government departments. In regard to engineering appointments, the Committee recommends that academic qualifications should not be allowed to overshadow the less easily assessable but great practical value of men who have graduated through the workshops to management level. It is also recommended that to meet the shortage of persons of managerial capacity, the Ministry of Labour should make a careful search for persons who might be up-graded above the level of their present employment.

The importance is stressed of the Ministry preparing in good time for the difficult post-war task of placing in civil employment the large numbers of men and women demobilized from the Armed Forces, and attention is also directed to the importance, as a means of remedying the shortage of technically qualified recruits in Government departments-and the remark applies equally to industry-of ensuring the most economical use of such persons after appointment. This involves a careful watch on the changing conditions of industry from the point of view of the technical help and supervision needed from the Supply departments. The report also includes a memorandum by Sir James Rae on the professional and technical staffs in Government departments which describes the work of the assessors appointed early last year. This review covers the elimination of functions not essential to the prosecution of the War, the elimination, following if necessary a relaxation of normal peace-time standards, of all work now entrusted to professionally and technically qualified staff which is not absolutely necessary for the discharge of those functions, reduction to a minimum of checking and 
reference to higher authority, increased collaboration between Departments with the view of avoiding overlapping of functions, a re-organization of the remaining work so as to make the minimum demands on professional qualifications, and to ensure that work not requiring such qualifications is devolved on persons less highly qualified. The report also recommends that delays in the payment of inereases of salary either as increments or as the result of promotion should be eliminated, and the immediate investigation of the alleged inadequacy of salaries paid to technical officers. The Committee regards it as fundamental that there should be a reasonable relation between the salaries paid by Government and industrial firms respectively.

\section{Agriculture in Northern Ireland}

AdDressing a meeting at Ballyclare, Northern Treland, Mr. J. F. Gordon, the Northern Ireland Minister of Labour, said that during the present year the farmers of Northern Ireland have surpassed all previous records in the production of food. They have increased land cultivation by 100 per cent, and obtained an agricultural turnover during the year of $£ 44,000,000$. After feeding the people of Northern Ireland and the troops stationed there the farmers have sent about $\$ 10,000,000$ worth of food, including $360,000,000$ eggs, to swell the larder in Great Britain. The Northern Ireland Ministry of Agriculture has pushed ahead with a scheme of potato processing plant, and it is hoped that nine factories will be completed in time to deal with the 1942 surplus crop, converting it into potato meal for animal feeding and into potato for human consumption.

\section{Depths of the Arctic Ocean}

A NOTE on some important Soviet flights in the Arctic is contained in the Polar Record of July. In March 1941 Ivan Cherevichni, and four others, flew from Moscow via Archangel, Franz Josef Land and Severnaya Zemlya to their base on Wrangel Island. Thence several flights were made to the north to investigate conditions in the least known area of the Arctic Sea. On the first flight a descent on the pack was made in lat. $81^{\circ} 2^{\prime} \mathrm{N}$., long. $180^{\circ} \mathrm{E}$., and for four days hydrographical observations were made. The ocean depth was $1,447 \mathrm{fm}$. The next flight was to lat. $78^{\circ} \mathrm{N}$., long. $176^{\circ} 40^{\prime} \mathrm{E}$., where the depth was $1,015 \mathrm{fm}$. , and the third flight was to lat $78^{\circ} \mathrm{N}$., long. $170^{\circ} \mathrm{E}$., where the depth was $1,878 \mathrm{fm}$. In the Cherevichni triangle, made by these three stations, the depths appear to be considerably less than the single sounding of Sir Hubert Wilkins in 1927 in lat. $77^{\circ} 45^{\prime} \mathrm{N}$., long. $175^{\circ} \mathrm{W}$., which was $2,830 \mathrm{fm}$. These discrepancies in depths were not expected in the Arctic Ocean. The physicist in the party found the intermediate layer of warm Atlantic water at all three stations. It will be recalled that this layer, first found by Nansen, was noted by Papanin, of the Soviet drifting polar station, some years ago. It is now fair to assume that it occurs throughout the Arctic basin.

\section{The Couvade}

Is the recently published September issue of FolkLore, Mr. L. F. Newman discusses the curious but widespread and ancient custom named couvade', which consists in the illness of the husband during his wife's pregnancy, parturition and puerperium.
He classifies the theories as to its origin in three groups according as they are held by (1) the classical school, who follow Apollonius Rhodius, Strabo, Plutarch and the other early writers; (2) the historians, who base their views on authors such as Marco Polo, Bacon, Butler and others; and (3) the anthropologists, who are influenced mainly by scientific data and records from the life of the more primitive peoples. Mr. Newman comes to the conclusion that a number of quite diverse customs have been grouped together under the name of the 'couvade', and that many are not different types of one definite custom, but are survivals of recorded instances of separate eustoms and are of multiple origin.

\section{Standardizing Electrical Instruments}

IN a paper read on December 3 in London before the Institution of Electrical Engineers, Lieut.-Col. K. Edgcumbe dealt with the standardization of industrial electrical instruments from the aspects of performance limits, dimensional limits and certain constructional features facilitating interchangeability and promoting commercial manufacture, and other minor matters such as preferred terms, definitions, symbols, etc. Comparisons are made of the standards issued in Great Britain, the United States and Germany and by the International Electrotechnical Commission, suggestions being put forward for the extension or amendment of the pertinent specifications issued by the British Standards Institution, notably BS81, $B S 89$ and $B S 90$.

\section{Announcements}

WE regret to announce the death of Sir Henry Miers, F.R.S., Waynflete professor of mineralogy in the University of Oxford during 1895-1908, principal of the University of London from 1908 until 1915, and vice-chaneellor of the University of Manchester and professor of crystallography during 1915-26, on December 10, aged eighty-four.

DR. G. A. R. Kow has been appointed as the first occupant of the University of London chair of chemistry tenable at the Royal Cancer Hospital (Free), which was instituted just before the outbreak of war. Dr. Kon has been a member of the staff of the Imperial College of Science and Technology since 1925 , the title of reader in organic chemistry being conferred on him in 1935 .

IT is announced that the estate of Sir Joseph Larmor, who died on May 19 (see Nature, June 6, p. 631), amounts to $£ 54,500$. He made the following bequests, among others : $£ 3,000$ to St. John's College, Cambridge, for annual rewards for undergraduates; $£ 3,000$ to the Royal Academical Institution, Belfast, to supplement scholarships; $£ 3,000$ to augment emoluments held by junior members in Northern Ireland of Queen's University, Belfast; $£ 2,000$ to the University of Cambridge to provide medical and other assistance to junior members of the University ; $£ 1,000$ each to St. John's College, Cambridge, and Magee University College, Londonderry; and £750 each to Trinity College, Dublin, and the National University of Ireland for the benefit of University College, Galway. Subject to other bequests, the residue is to be used for increasing the educational bequests to St. John's College, Cambridge, the Royal Belfast Academical Institution, and Queen's University, Belfast. 